\section{Section Editor}

Mitchell S.V. Elkind, MD, MS

Benjamin R. Wakerley, PhD, MRCP

Mei Hong Tan, MB, $\mathrm{ChB}, \mathrm{BAO}, \mathrm{PhD}$, FRCOphth

Martin R. Turner, PhD, FRCP

Correspondence \& reprin requests to Dr. Turner: martin.turner@ndcn.ox.ac.uk

\title{
Teaching Video NeuroImages: Acute Adie syndrome
} 回

A healthy 30-year-old woman reported acute painless enlargement of the right pupil, associated with mild ipsilateral photophobia and blurring. An enlarged right pupil was observed, constricting poorly to light and with segmental vermiform movements (figure). Generalized deep tendon hyporeflexia was noted. The tonic right pupil constricted 30 minutes after instillation of dilute pilocarpine (0.1\%) solution. William John Adie $^{1}$ (1886-1935) described this benign condition predominantly in young women, postulated to be secondary to viral ciliary ganglionitis. Russell ${ }^{2}$ noted cases with a poor near as well as light response, which we postulate may be a feature of an acute syndrome.

\section{REFERENCES}

1. Adie WJ. Tonic pupils and absent tendon reflexes: a benign disorder sui generis; its complete and incomplete forms. Brain 1932;55:98-113.

2. Russell GFM. The pupillary changes in the Holmes-Adie Syndrome. J Neurol Neurosurg Psychiatry 1956;19:289296.
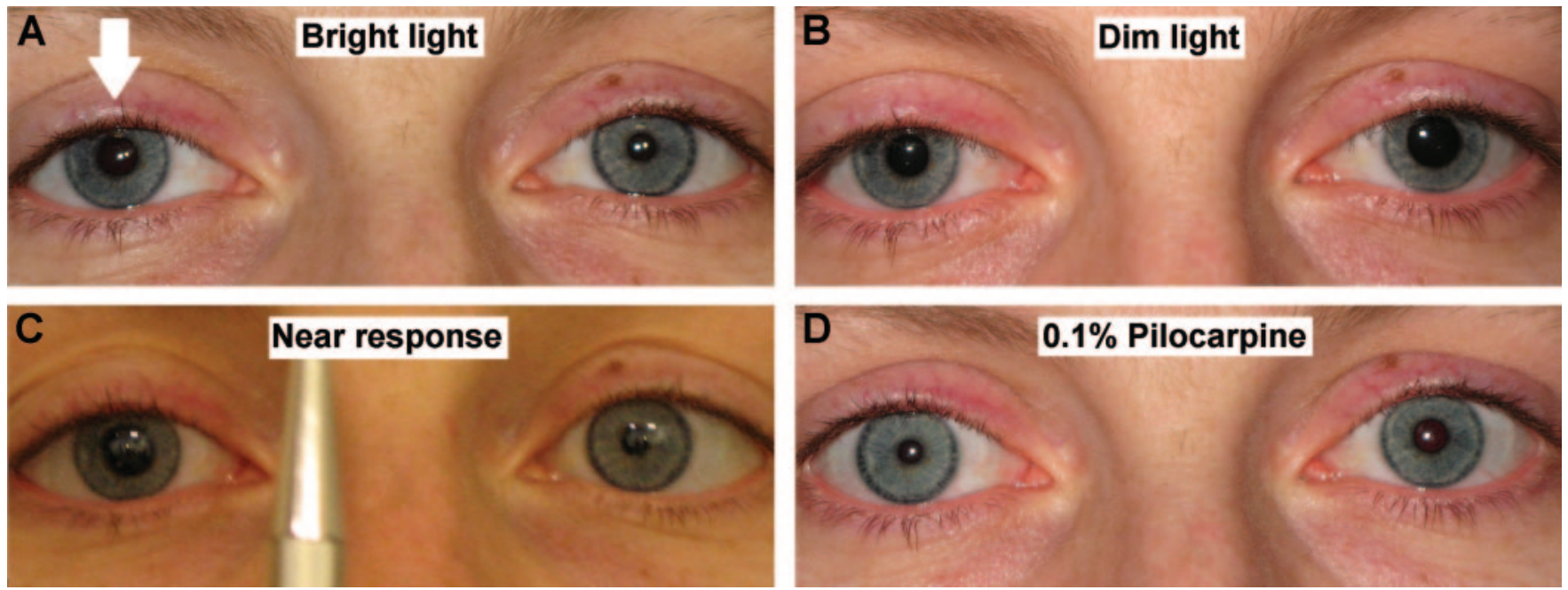

Parasympathetic denervation of the iris sphincter muscle in Adie syndrome results in an enlarged tonic right pupil reacting poorly to light (A, B). Near response was also impaired (C). It is supersensitive to cholinergic agents (pilocarpine $0.1 \%$ ) (D). Paralysis of the iris results in characteristic segmental vermiform movements. These are visible superolaterally acutely and inferomedially 6 months later (video on the Neurology ${ }^{\circledR}$ Web site at www.neurology.org). 


\section{Neurology}

\section{Teaching Video NeuroImages: Acute Adie syndrome}

Benjamin R. Wakerley, Mei Hong Tan and Martin R. Turner

Neurology 2012;79;e97

DOI 10.1212/WNL.0b013e3182698cc5

This information is current as of September 10, 2012

\section{Updated Information \& \\ Services \\ Supplementary Material \\ References \\ Subspecialty Collections}

Permissions \& Licensing

Reprints including high resolution figures, can be found at:

http://n.neurology.org/content/79/11/e97.full

Supplementary material can be found at:

http://n.neurology.org/content/suppl/2012/09/08/79.11.e97.DC1

This article cites 2 articles, 1 of which you can access for free at: http://n.neurology.org/content/79/11/e97.full\#ref-list-1

This article, along with others on similar topics, appears in the following collection(s):

Clinical neurology examination

http://n.neurology.org/cgi/collection/clinical_neurology_examination

Pupils

http://n.neurology.org/cgi/collection/pupils

Viral infections

http://n.neurology.org/cgi/collection/viral_infections

Information about reproducing this article in parts (figures,tables) or in its entirety can be found online at:

http://www.neurology.org/about/about_the_journal\#permissions

Information about ordering reprints can be found online: http://n.neurology.org/subscribers/advertise

Neurology ${ }^{\circledR}$ is the official journal of the American Academy of Neurology. Published continuously since 1951, it is now a weekly with 48 issues per year. Copyright Copyright $@ 2012$ by AAN Enterprises, Inc.. All rights reserved. Print ISSN: 0028-3878. Online ISSN: 1526-632X.

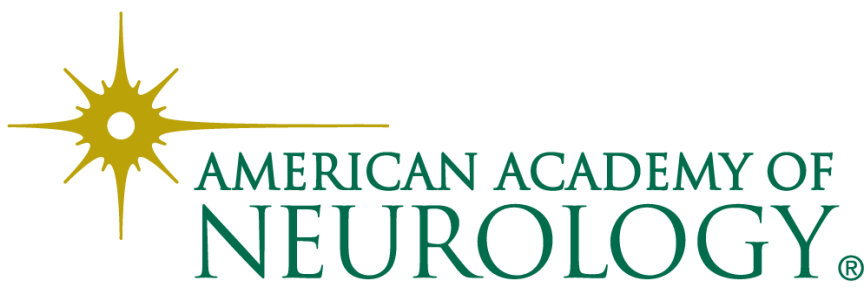

